\title{
Parameters Estimation of \\ Generalized Richards Model for COVID-19 Cases in Indonesia Using Genetic Algorithm
}

\author{
Maya Rayungsari ${ }^{1,2, *}$, Muhammad Aufin² ${ }^{2}$, Nurul Imamah ${ }^{1,3}$ \\ ${ }^{1}$ Department of Mathematics, Faculty of Mathematics and Natural Sciences, Brawijaya University, Indonesia \\ ${ }^{2}$ Department of Mathematics Education, PGRI Wiranegara University, Pasuruan, Indonesia \\ ${ }^{3}$ Department of Mathematics Education, University of Muhammadiyah Jember, Indonesia \\ *Corresponding author: maya.rayungsari@gmail.com
}

\begin{abstract}
In this research, genetic algorithm was implemented to estimate parameters in generalized Richards model by adjusting COVID-19 case data in Indonesia. Data collected were the daily new cases and cumulative number of COVID-19 case in Indonesia from early March to early June 2020, that was reported by databoks.katadata.co.id. The best pair of parameters was selected based on the lowest cost function value, determined from the distance between data with estimated model and real data. Next, model with estimated parameters is used to predict new cases and cumulative cases for upcoming days. Numerical simulations were carried out so that the peaks and ends of the COVID-19 pandemic can be seen easily.
\end{abstract}

Keywords: Parameters Estimation; Generalized Richards Model,; COVID-19; Genetic Algorithm

\section{Introduction}

Novel coronavirus (COVID-19) was first identified in Wuhan, China, in the end of year 2019. That virus had been researched and identified as a genus betacoronavirus, the same as other acute and severe diseases Respiratory Syndrome (SARS) and the Middle East Respiratory Syndrome (MERS) [1]. This virus has become epidemic in China and also spread to other countries very quickly. It has brought big impact in all sectors of human life. Therefore, many scientists study COVID-19 in various perspectives and goals. In mathematics, many forecasting is done to find out when the covid-19 pandemic will end.

One mathematical model about the spread of disease that is widely studied by mathematicians to predict cases in epidemiology is [2-4]

$$
\frac{d C(t)}{d t}=r C(t)^{p}\left(1-\left(\frac{C(t)}{K}\right)^{a}\right)
$$

where $C(t)$ is the cumulative number of cases at time $t, r$ is the growth rate in the initial stages, and $K$ is the final epidemic measure. $p \in[0,1]$ is a parameter that allows the model to describe different growth profiles including constant events $(p=0)$, sub-exponential growth $(0<p<1)$, and exponential growth $(p=1)$. Model (1) is the generalization from Richards model [5]

$$
\frac{d C(t)}{d t}=\frac{r}{a} C(t)\left(1-\left(\frac{C(t)}{K}\right)^{a}\right)
$$

so the model (1) is called by generalized Richards model.

Nuraini et. al [6], predicted the number of COVID-19 cases in Indonesia using the Richards model and obtained the results that the peak of the epidemic in Indonesia would be occured at the end of March 2020 and would be ended in the middle of April 2020. However, the that prediction did not match the real data that happened in reality for until the end of May 2020 the number of new cases per day was still relatively increasing. Indeed, there is no model that really fits the real data. In addition, many factors influence the differences between estimated model and real data in the COVID-19 case in Indonesia, such as the lack of community efforts to carry out physical distancing or adhere to health protocols recommended by WHO. 
In this study, estimations were performed to all four parameters $r, p, K$, and $a$ in model (1) using genetic algorithm. According to Carwoto [7], genetic algorithm is a search algorithm based on Darwin's natural selection mechanism and genetic principles, for high-quality individuals found in a domain (population). The search is carried out with an iterative procedure to regulate the population of individuals who are candidates for the solution. This genetic algorithm has been reviewed by many researchers to estimate parameters (curve fitting) [8-10]. In this study, continuous genetic algorithms are used because the variables used are in the form of decimal numbers. The difference with the binary genetic algorithm is that in a continuous genetic algorithm, there is no need to decode.

\section{Methods}

First of all, researchers collected data of COVID-19 case in Indonesia from March, 2 until June, 8 of 2020. Then, the parameters in generalized Richards model was estimated using the Genetic Algorithm with Matlab 2018 software. In Genetic Algorithm, some features are needed, namely generations number (number of iterations), populations number (number of paired parameters), crossover point, mutation rate, and weighting constant. In this study, the generations number was 100 and populations number is 200. The crossover point for each parameter's mating was random from 1 until variable (parameter) number minus 1, the weighting constant for each generation was random real number between 0 and 1 , and mutation rate of 0.1 was selected.

Estimate of twenty experiments was carried out. From all of the experiments, the parameters with the lowest cost are selected, which have the smallest difference with real data. The next step is simulating the model using the best estimated parameters numerically to predict the new cases and cumulative cases for upcoming days.

\section{Results and Discussion}

\subsection{Parameters Estimation}

The address databoks.katadata.co.id [11] presents data on the number of new cases and the cumulative number of COVID-19 cases in Indonesia as in Table 1 and simulated in Figure 1,Figure 2.

Table 1. Data of COVID-19 cases in Indonesia

\begin{tabular}{ccc}
\hline Date & New Case & Cumulative Case \\
\hline $2020-03-02$ & 2 & 2 \\
$2020-03-03$ & 0 & 2 \\
$2020-03-04$ & 0 & 2 \\
$2020-03-05$ & 0 & 2 \\
$2020-03-06$ & 2 & 4 \\
$2020-03-07$ & 0 & 4 \\
$2020-03-08$ & 2 & 6 \\
$2020-03-09$ & 13 & 19 \\
$2020-03-10$ & 8 & 27 \\
$2020-03-11$ & 7 & 34 \\
$2020-03-12$ & 0 & 34 \\
$2020-03-13$ & 35 & 69 \\
$2020-03-14$ & 27 & 96 \\
$2020-03-15$ & 21 & 117 \\
$2020-03-16$ & 17 & 134 \\
$2020-03-17$ & 38 & 172 \\
$2020-03-18$ & 55 & 227 \\
$2020-03-19$ & 82 & 309 \\
$2020-03-20$ & 60 & 369 \\
$2020-03-21$ & 81 & 450 \\
$2020-03-22$ & 64 & 514 \\
$2020-03-23$ & 65 & 579 \\
$2020-03-24$ & 107 & 686 \\
$2020-03-25$ & 105 & 790 \\
\hline
\end{tabular}

Based on the results in Table 2, the parameters pair with the lowest cost are $r=1.067549, p=0.670103, K=65151$, and $a=0.930868$. Numerical simulations in Figure 3 and Figure 4 with the values of those parameters give the 


\begin{tabular}{|c|c|c|}
\hline Date & New Case & Cumulative Case \\
\hline $2020-03-26$ & 103 & 893 \\
\hline 2020-03-27 & 153 & 1046 \\
\hline $2020-03-28$ & 109 & 1155 \\
\hline $2020-03-29$ & 130 & 1285 \\
\hline $2020-03-30$ & 129 & 1414 \\
\hline 2020-03-31 & 114 & 1528 \\
\hline 2020-04-01 & 149 & 1677 \\
\hline 2020-04-02 & 113 & 1790 \\
\hline 2020-04-03 & 196 & 1986 \\
\hline 2020-04-04 & 106 & 2092 \\
\hline 2020-04-05 & 181 & 2273 \\
\hline 2020-04-06 & 218 & 2491 \\
\hline 2020-04-07 & 247 & 2738 \\
\hline 2020-04-08 & 218 & 2956 \\
\hline 2020-04-09 & 337 & 3293 \\
\hline 2020-04-10 & 219 & 3512 \\
\hline 2020-04-11 & 330 & 3842 \\
\hline 2020-04-12 & 399 & 4241 \\
\hline 2020-04-13 & 316 & 4557 \\
\hline 2020-04-14 & 282 & 4839 \\
\hline 2020-04-15 & 297 & 5136 \\
\hline 2020-04-16 & 380 & 5516 \\
\hline 2020-04-17 & 407 & 5923 \\
\hline 2020-04-18 & 325 & 6248 \\
\hline 2020-04-19 & 327 & 6575 \\
\hline $2020-04-20$ & 185 & 6760 \\
\hline 2020-04-21 & 375 & 7135 \\
\hline $2020-04-22$ & 283 & 7418 \\
\hline $2020-04-23$ & 357 & 7775 \\
\hline 2020-04-24 & 436 & 8211 \\
\hline $2020-04-25$ & 396 & 8607 \\
\hline $2020-04-26$ & 275 & 8882 \\
\hline 2020-04-27 & 214 & 9096 \\
\hline $2020-04-28$ & 415 & 9511 \\
\hline $2020-04-29$ & 260 & 9771 \\
\hline 2020-04-30 & 347 & 10118 \\
\hline 2020-05-01 & 433 & 10551 \\
\hline $2020-05-02$ & 292 & 10843 \\
\hline $2020-05-03$ & 349 & 11192 \\
\hline 2020-05-04 & 395 & 11587 \\
\hline 2020-05-05 & 484 & 12071 \\
\hline $2020-05-06$ & 367 & 12438 \\
\hline 2020-05-07 & 338 & 12776 \\
\hline 2020-05-08 & 336 & 13112 \\
\hline 2020-05-09 & 533 & 13645 \\
\hline 2020-05-10 & 387 & 14032 \\
\hline 2020-05-11 & 233 & 14265 \\
\hline 2020-05-12 & 484 & 14749 \\
\hline 2020-05-13 & 689 & 15438 \\
\hline 2020-05-14 & 568 & 16006 \\
\hline 2020-05-15 & 490 & 16496 \\
\hline $2020-05-16$ & 529 & 17025 \\
\hline 2020-05-17 & 489 & 17514 \\
\hline 2020-05-18 & 496 & 18010 \\
\hline 2020-05-19 & 486 & 18496 \\
\hline $2020-05-20$ & 693 & 19189 \\
\hline 2020-05-21 & 973 & 20162 \\
\hline $2020-05-22$ & 634 & 20796 \\
\hline
\end{tabular}




\begin{tabular}{ccc}
\hline Date & New Case & Cumulative Case \\
\hline $2020-05-23$ & 949 & 21745 \\
$2020-05-24$ & 526 & 22271 \\
$2020-05-25$ & 479 & 22750 \\
$2020-05-26$ & 415 & 23165 \\
$2020-05-27$ & 686 & 23851 \\
$2020-05-28$ & 687 & 24538 \\
$2020-05-29$ & 678 & 25216 \\
$2020-05-30$ & 557 & 25773 \\
$2020-05-31$ & 700 & 26473 \\
$2020-06-01$ & 467 & 26940 \\
$2020-06-02$ & 609 & 27549 \\
$2020-06-03$ & 684 & 28233 \\
$2020-06-04$ & 585 & 28818 \\
$2020-06-05$ & 703 & 29521 \\
$2020-06-06$ & 993 & 30514 \\
$2020-06-07$ & 672 & 31186 \\
$2020-06-08$ & 847 & 32033 \\
\hline
\end{tabular}

prediction that the addition of new cases of COVID-19 in Indonesia reached the peak in early June 2020 of around 600 cases. In addition, it was also found that the COVID-19 pandemic in Indonesia is predicted to be ended in the middle of February 2021 with the maximum cumulative amount of 65067. This result is very much different from the results in the forecasting described earlier [6]. These results appear to be more in line with real data. However, the results obtained in this study are not very consistent with the real data considering the number of new cases added had reached 993 on June, 62020.

Table 2. The results of parameters estimation using genetics algorithm

\begin{tabular}{cccccc}
\hline Experiment & $r$ & $p$ & $K$ & $a$ & cost \\
\hline 1 & 0.716706 & 0.743492 & 62707.587272 & 0.579636 & 52.870182 \\
2 & 0.736008 & 0.742655 & 69814.858676 & 0.519414 & 48.878518 \\
3 & 0.594692 & 0.808475 & 61413.507735 & 0.315397 & 59.411524 \\
4 & 0.830725 & 0.703028 & 70854.035223 & 0.887212 & 56.510482 \\
5 & 1.067549 & 0.670103 & 65151.394033 & 0.930868 & 45.079011 \\
6 & 1.240251 & 0.650344 & 76703.231660 & 0.851824 & 48.201949 \\
7 & 0.759724 & 0.732778 & 55119.635198 & 0.659499 & 60.431946 \\
8 & 1.339886 & 0.640612 & 70923.495648 & 0.892240 & 60.789361 \\
9 & 0.609063 & 0.773894 & 45792.859491 & 0.601184 & 77.641809 \\
10 & 0.709855 & 0.749629 & 62158.455983 & 0.531452 & 54.458610 \\
11 & 0.754731 & 0.742767 & 72629.942305 & 0.478006 & 48.034166 \\
12 & 0.756733 & 0.732361 & 63397.824797 & 0.622663 & 51.284776 \\
13 & 0.559986 & 0.803320 & 45142.740320 & 0.453807 & 85.953706 \\
14 & 0.896984 & 0.695427 & 64643.666655 & 0.877027 & 46.146775 \\
15 & 0.685327 & 0.765630 & 63295.738195 & 0.434663 & 56.353092 \\
16 & 0.610825 & 0.780651 & 52446.851536 & 0.486624 & 67.333387 \\
17 & 0.898740 & 0.693779 & 69689.676954 & 0.870242 & 45.925880 \\
18 & 1.039024 & 0.683308 & 54353.199361 & 0.797504 & 74.212424 \\
19 & 0.915574 & 0.718942 & 51373.671962 & 0.546007 & 101.067937 \\
20 & 1.164601 & 0.659994 & 70517.011444 & 0.860662 & 49.241770 \\
\hline
\end{tabular}

\section{Conclusion}

Based on the results and discussion previously described, it was concluded that generalized Richards model with the best parameters fit with the real data of COVID-19 cases in Indonesia was

$$
\frac{d C(t)}{d t}=1.067549 C(t)^{0.670103}\left(1-\left(\frac{C(t)}{65151}\right)^{0.930868}\right) .
$$




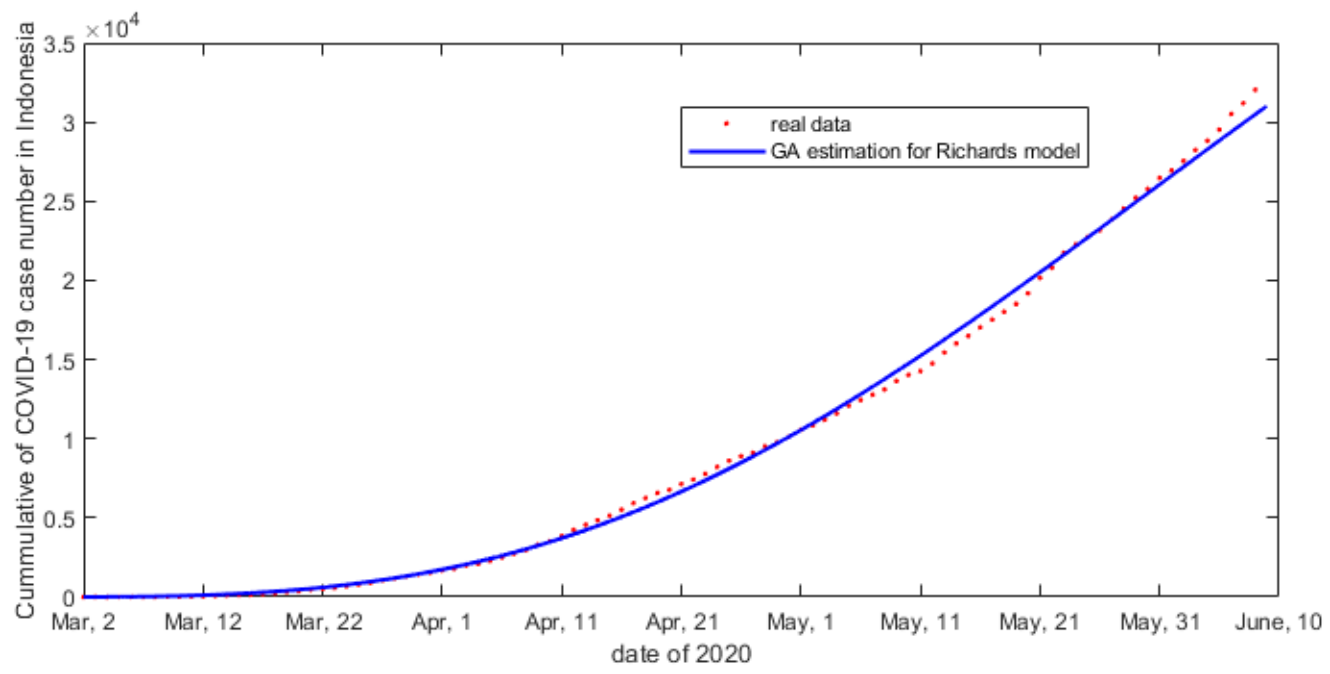

Figure 1. COVID-19 Cumulative Number in Indonesia

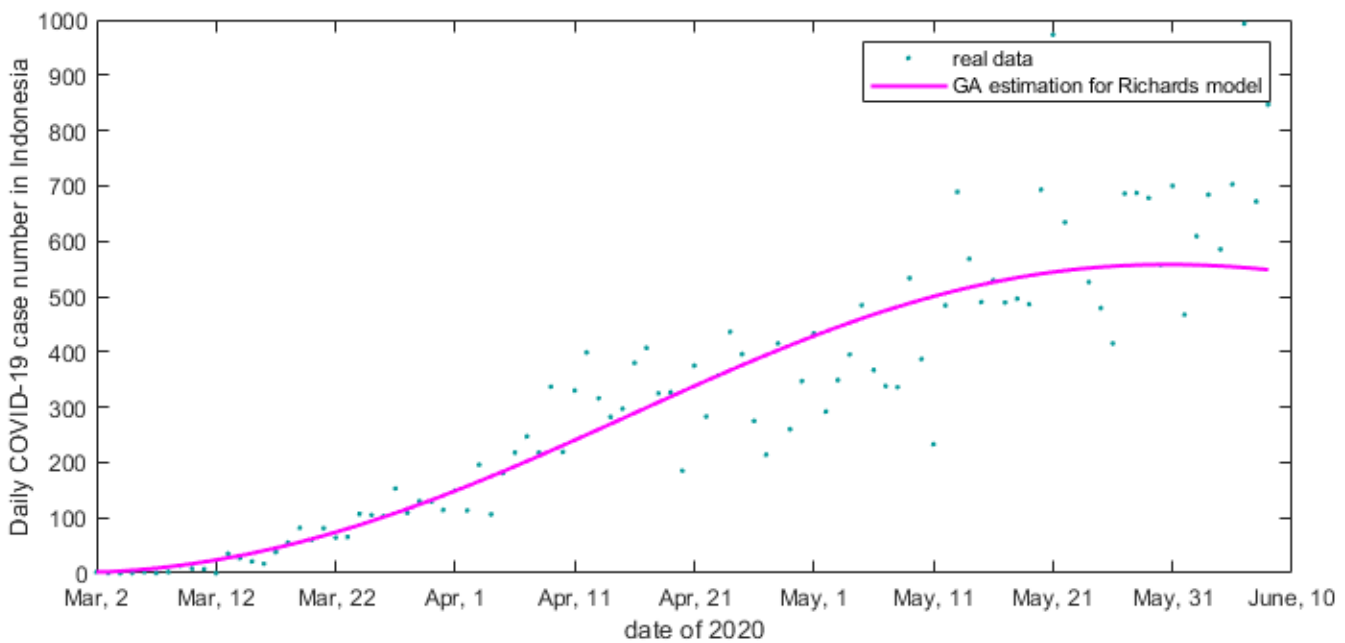

Figure 2. Daily COVID-19 New Case in Indonesia

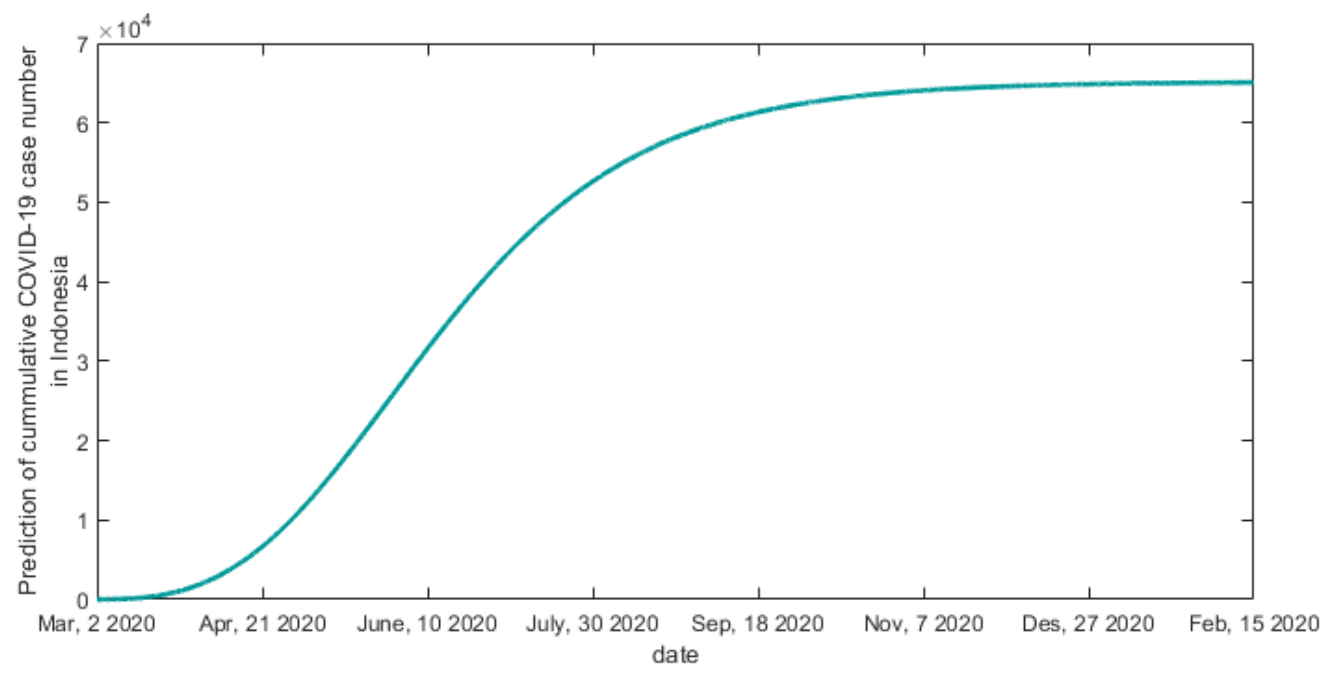

Figure 3. Prediction of COVID-19 Cumulative Number in Indonesia

Numerical simulations showed that the daily new cases would be reached the peak in early June 2020 of around 600 cases and would be ended in the middle of February 2021 with the maximum cumulative amount of 65067. 


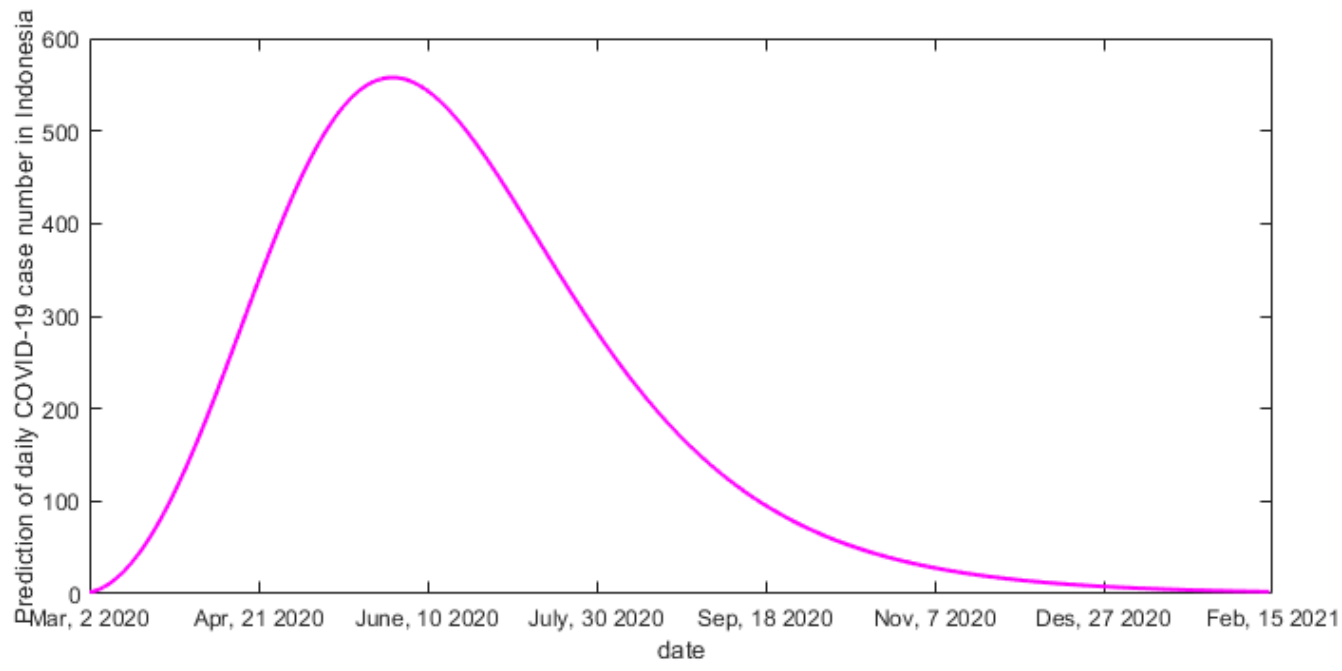

Figure 4. Prediction of Daily COVID-19 New Case in Indonesia

\section{References}

[1] N. C. Peeri, N. Shrestha, M. S. Rahman, R. Zaki, Z. Tan, S. Bibi, M. Baghbanzadeh, N. Aghamohammadi, W. Zhang, and U. Haque, "The SARS, MERS and novel coronavirus (COVID-19) epidemics, the newest and biggest global health threats: what lessons have we learned?" International Journal of Epidemiology, 2020.

[2] C. Viboud, L. Simonsen, and G. Chowell, "A generalized-growth model to characterize the early ascending phase of infectious disease outbreaks," Epidemics, vol. 15, pp. 27-37, 2016.

[3] G. Chowell, "Fitting dynamic models to epidemic outbreaks with quantified uncertainty: A primer for parameter uncertainty, identifiability, and forecasts," Infectious Disease Modelling, vol. 2, no. 3, pp. 379-398, 2017.

[4] A. Szparaga and S. Kocira, "Generalized logistic functions in modelling emergence of Brassica napus L." PLOS ONE, vol. 13, no. 8, p. e0201980, 2018.

[5] F. J. Richards, “A Flexible Growth Function for Empirical Use," Journal of Experimental Botany, vol. 10, no. 2, pp. 290-301, 1959.

[6] N. Nuraini, K. Khairudin, and M. Apri, "Modeling Simulation of COVID-19 in Indonesia based on Early Endemic Data," Commun. Biomath. Sci., vol. 3, no. 1, pp. 1-8, 2020.

[7] Carwoto, "Implementasi Algoritma Genetika untuk Optimasi Penempatan Kapasitor Shunt pada Penyulang Distribusi Tenaga Listrik," Jurnal Teknologi Informasi DINAMIK, vol. 12, pp. 122-130, 2007.

[8] M. Rayungsari, N. Imamah, A. Imaniyah, and V. B. Kusuma, "Estimasi Parameter Model Predator-prey Menggunakan Algoritma Genetika," Jurnal Gammath, vol. 4, pp. 103-112, 2019.

[9] S. Anam, "Parameters Estimation of Enzymatic Reaction Model for Biodiesel Synthesis by Using Real Coded Genetic Algorithm with Some Crossover Operations," IOP Conference Series: Materials Science and Engineering, vol. 546, p. 052006, 2019.

[10] R. D. Hidayaturrachmah, S. Anam, and Marjono, “Allocation of Thesis Supervisor Using Genetic Algorithm," Jurnal EECCI, vol. 12, pp. 26-32, 2018.

[11] S. Fitra, “Total Kasus \& Kasus Baru Covid-19, https:/ /databoks.katadata.co.id/datapublish/2020/06/08/Kasus-Covid19-Bertambah-847-Kasus-Senin-86\#, diakses tanggal 8 Juni 2020 ." 